\title{
Transformational Communities: A Programmatic Ambivalence as a Learning Path for the Cognitive Planet
}

\author{
Paulo Castro Seixas ${ }^{1} \&$ Nadine Lobner ${ }^{1}$ \\ ${ }^{1}$ Centro de Administração e Politicas Publicas, Portugal \\ Correspondence: Nadine Lobner, Centro de Administração e Politicas Publicas, Portugal. E-mail: \\ nlobner@iscsp.ulisboa.pt
}

Received: August 16, 2018

Accepted: September 22, 2018

Online Published: November 29, 2018

doi:10.5539/jsd.v11n6p152

URL: https://doi.org/10.5539/jsd.v11n6p152

\begin{abstract}
The following article outlines a proposal of a Programmatic Ambivalence as learning path, built from bottom-up and top-down Agendas (Minimalist/Maximalist) of the Sustainable Development Goals. This discussion is placed in the framework of the 2030 Agenda, as well as in the challenge of the Anthropocene. The idea of a Lobby of People is referred for the replication of learning experiences as transformational plans everywhere. To contribute to the importance of a circulation between bottom-up and top-down construction, challenging exploratory models through transformed Communities of Practices are presented.
\end{abstract}

Keywords: programmatic ambivalence, minimalist/maximalist agenda, communities of practices, sustainable development goals, anthropocene, transformation

\section{Introduction: Learning Experiences to Promote the Process of Learning Itself?}

This paper is encouraged, firstly, by an analysis of the key documents of the process of preparations for the post-2015 Agenda and, secondly, by the analysis from the policy document of 2014 that proposed the SDG to the world (UN 2014) as well as of the final document from September 2015 (UN 2015). Throughout this analysis, this paper aims to argue that both the preparation of the agenda and the agenda itself represent a learning path that intends to promote the process of learning to learn everywhere. We propose that the SDGs must not be handled as the MDGs (a top-down process only), what requires the outstanding change of the mindset for the essentiality of a circulation between bottom-up and top-down structures. Therefore, we propose a new concept as well as exploratory ways for implementing it: A Programmatic Ambivalence as a way of processing the Minimalist/Maximalist Agendas of the SDGs. Elaborated on section two we are going to provide an extended perception on these circulating ideas and practices.

The Programmatic Ambivalence, expressed in the preparation of and inside the agenda means, in fact, a double bound process (top-down and bottom-up approach) that must be implemented as a transformational plan to promote learning experiences for modification processes everywhere. If we agree with all these arguments, this must be seriously considered by educational institutions at all levels since there will be no more substantial role than the one of promoting Transformational CoP. Grounded on that assumption, empirical practices throughout qualitative methods will be shown as to create what we call a Lobby of People (a bottom-up movement with various learning experiences) as well as transformational plans at all levels for a general learning path in a cognitive planet. Development went along the history of transformation from a dual process to a global one: evolving from dichotomies (first vs. third worlds, developed vs. developing) to a thematic global focus with MDG and finally to a planetary focus with SDG.

Referring to the Agenda 2030 in context of the Sustainable Development Goals, further discussion about the Conference Rio+20 (13-22 June 2012) is mandatory. This conference represented the take off for the Post-2015 Agenda. The state-members accepted to define universal Sustainable Development Goals and launched the process for their elaboration in the document that came out of the Conference "The Future We Want". The challenge of 'mapping a new path' and the effort of defining a new global public policy was partly coordinated with 'The Secretary-General's High-Level Panel of Eminent Persons on the Post-2015 Development Agenda'. The constitution of this panel was announced on the same conference by the Secretary-General at that time, Ban Ki-Moon. 
The process took two and a half years and by the $4^{\text {th }}$ of December 2014 'The Road to Dignity by 2030' (UN 2014) was presented as the first policy document on the post-2015 agenda. The final policy document confirming the SDG layout was presented at the UN General Assembly of September 2015 in New York, wherefore by now it is possible to attain interpretations of what Development means in the Agenda that will lead us until 2030. For better insight, the following graphic demonstrates the schedule and the preparation documents of the post-15 agenda.

Table 1. Documents of the post-2015 Agenda (2012-2013)

\begin{tabular}{|c|c|}
\hline Schedule & Documents \\
\hline 2012 & Report of the UN System Task Team on the Post-2015 UN Development Agenda - Realizing the \\
\hline \multirow[t]{2}{*}{ January } & Future We Want for All - Report to the Secretary-General \\
\hline & http://www.un.org/millenniumgoals/pdf/Post_2015_UNTTreport.pdf \\
\hline \multirow[t]{2}{*}{ June } & Final document Rio+20 - “The Future We Want. Our Common Vision" - June 2012 \\
\hline & http://sustainabledevelopment.un.org/futurewewant.html \\
\hline \multirow[t]{5}{*}{ June } & Concept Note of UN Habitat (2012). "Sustainable cities and human settlements in the post-2015 \\
\hline & UN development agenda. Concept note. \\
\hline & http://sustainabledevelopment.un.org/content/documents/1653SustainableCities.pdf \\
\hline & SDSN Report- "An Action Agenda for Sustainable Development" \\
\hline & http://unsdsn.org/files/2013/11/An-Action-Agenda-for-Sustainable-Development.pdf \\
\hline \multirow[t]{3}{*}{2013 May } & High Level Panel Report- A New Global Partnership: Eradicate Poverty And Transform \\
\hline & Economies $\quad$ Through \\
\hline & http://www.post2015hlp.org/wp-content/uploads/2013/05/UN-Report.pdf \\
\hline \multirow[t]{2}{*}{ May } & World Economic and Social Survey - 2013 \\
\hline & http://www.un.org/en/development/desa/policy/wess/wess_current/wess2013/WESS2013.pdf \\
\hline \multirow[t]{2}{*}{ July } & The World We Want: A Million Voices \\
\hline & http://www.worldwewant2015.org/millionvoices \\
\hline \multirow[t]{3}{*}{ September } & Statistics and Indicators for the Post-2015 Development Agenda \\
\hline & http://www.un.org/en/development/desa/policy/untaskteam_undf/UNTT_MonitoringReport_WE \\
\hline & B.pdf (finalized in in July) \\
\hline \multirow[t]{2}{*}{ September } & General Secretary Report - "A life of Dignity for all” (delivered in July) \\
\hline & http://www.un.org/en/ga/search/view_doc.asp?symbol=A/68/202 \\
\hline \multirow[t]{2}{*}{ September } & Final Document special session UN general Assembly on MDG \& agenda Post-2015 \\
\hline & http://post2015.iisd.org/guest-articles/leaving-no-one-behind-towards-a-post-2015-development-a \\
\hline \multirow[t]{3}{*}{ September } & High Level Panel on Global Sustainability Report - Resilient People Resilient Planet. A Future \\
\hline & Worth Choosing \\
\hline & http://www.un.org/gsp/sites/default/files/attachments/GSP_Report_web_final.pdf \\
\hline
\end{tabular}

Source: Elaboration of the authors

\section{Methodology}

Our arguments will be placed in three moments. Firstly, through a brief analysis of the agenda preparations, based on previous researches (Seixas, 2014), where the Programmatic Ambivalence was perceived as a learning path to respond to the Anthropocene. Secondly, over an interpretation of the SDG documents of 2014 and 2015, focusing particularly on the evidence of that Programmatic Ambivalence for further discussions about the meaning of a 'Transformational Approach' proposal in the context of the Minimalist/Maximalist Agenda. Finally, 
along a demonstration that the challenge of the Governance of the Resilience within the Anthropocene (Walker and Salt, 2006: 9; Seixas, 2014) is synonymous to a learning path that must be embodied in all individuals, organizations and communities as a reframing agenda for social change through Transformational Communities of Practices (Lave and Wenger, 1991; Wenger, 1998; Wenger et al. 2002).

To provide a detailed perception of the announced concepts and projects, we will continue with a precise discussion on an analytic foundation of the Programmatic Ambivalence in relation to the Minimalist/Maximalist Agenda.

\section{Discussion}

\subsection{The Programmatic Ambivalence: A transformational approach within the Minimalist/Maximalist Agenda}

The Programmatic Ambivalence as a concept contains, in order of a transformational approach, the discussion of a circulating bottom-up and top-down construct to make progress on the frame of the Sustainable Development Goals. Referring to the 2030 Agenda it seems more than necessary to target on the challenge of the Anthropocene within the preparations of a new learning path. Furthermore, a deeper insight to transformational processes for a better understanding is fundamental. The first global policy for development, the MDG, was built at a rational of state, perspective and control, therefore within a top-down motivation. In the agenda process of the SDG between 2012 and 2015, a change in the structure of this top-down procedure took its place as can be seen in the report of a million voices (July 2015), where people from all over the world shared their ideas about the conditions and forms for the future development agenda to promote once more that no individual should be left behind. Hence, transforming our world needs to be a task for everyone, this means that every person and entity must have an active role on the process, as Julia Guivant summarizes in Ulrich Beck's Legacy:

„This would be one of the possible spaces of reflexivity, away from the institutions representing the Nation-State, especially political parties, and where cooperation could emerge among international institutions (top-down globalization) and among local actors trans-nationally bonded (bottom-up globalization). Class, as a category of social change, is replaced by these new social and political actors, who do have the possibility of challenging the dominant structures while organizing around everyday issues (feminism, environmentalism, anti-war, anti-nuclear, etc.).“(Guivant, 2006)

Therefore, a top-down agenda must be linked and connected with a bottom-up agenda: certainly, in a Programmatic Ambivalence. The connection between the Anthropocene and the Programmatic Ambivalence origins in a Lobby of People and its circulating structures which enable new planetary coping processes. If in the MDG momentum change occurs through a process of government and acculturation, we suggest that with the SDGs there seems to be an awareness of the relevance of governance and enculturation. It is necessary to focus on the foundation of both phenomena to achieve a broad understanding of the importance of an interrelation between bottom-up and top-down development under the circumstances of the SDG.

MDGs

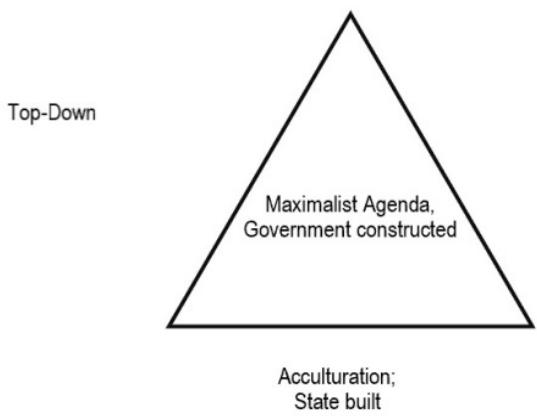

SDGs - Transformation and Experience

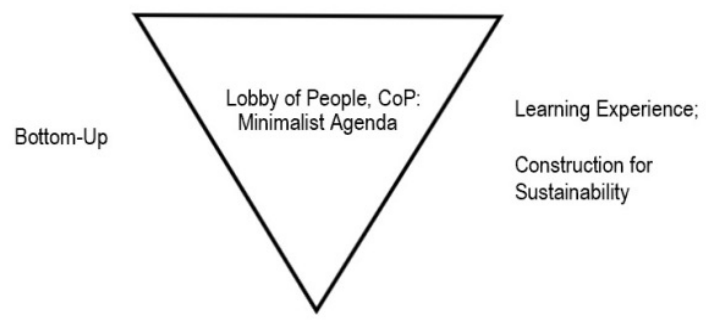

People based; several projects

Figure 1. Bottom-Up and Top-Down development

Source: Elaboration of the authors

This two graphics demonstrate the ambivalence between the Minimalist and the Maximalist Agenda. The Minimalist Agenda operates on a bottom-up development throughout what we emphasize as the Lobby of People. Several projects arise from people-based constructions, on the grounds of Communities of Practices. Under this 
process of enculturation, a learning experience upon a framework for sustainability emerges. As Walker and Salt (2006) cite, it is fundamental to demonstrate the progressive role of the actors in the stages of planning, implementing, monitoring and evaluating learning processes. Therefore, a Lobby of People has the power to influence the government for a change within stable constitutions. On the contrary, the Maximalist Agenda operates through a top-down system which is government-constructed, state built and based on acculturation processes. Therefore, one of the main necessities lies in the debate of a change within change, like an Urban Acupuncture after Marco Casagrande (Casagrande, 2015). The concept of the Urban Acupuncture emerges from the idea of small-scale interventions from every individual to transform the larger urban context. The result of such a revitalization movement (Wallace, 1956) can be seen as a dialogue between the citizens and the government in order to develop an interacting urban space.

„This strategy views cities as living, breathing organisms and pinpoints areas in need of repair. Sustainable projects, then, serve as needles that revitalize the whole by healing the parts. By perceiving the city as a living creature, thoroughly intertwined, "urban acupuncture" promotes communitarian machinery and sets localized nucleus - similar to the human body's meridians" (Casagrande, 2015: 22).

This strategy provides the opportunity for every individual to participate on modifications and development, interacting on a Minimalist/Maximalist scale. Taking this argument into account, the focus is on local resources and promotes the ideology of bottom-up interventions to improve the urban area. Such interventions address both the Lobby of People and the Government. It seems fundamental to deal with sustainability on a small scale that focuses on bottom-up instead of only on top-down structures. The MDG are considered as state built and therefore designed for top-down processes, hence, the SDG policy was built on a bottom-up agenda why fore it should finally be turned into practice. This, therefore, is the Programmatic Ambivalence within SDG. Certainly, it is obligatory to show the foundation of both phenomena within the debate of the Anthropocene to achieve a broad understanding of the necessity of an interrelation between bottom-up and top-down development under the circumstances of the SDG.

\subsection{The Anthropocene Challenge and the Programmatic Ambivalence}

At the opening of the Rio+20 meeting in June 2012, Ban Ki-Moon presented a short video clip titled "Welcome to the Anthropocene" as a statement. A new geological era in the history of planet Earth, called Anthropocene, was under discussion (Zalasiewicz et al., 2008; Zalasiewicz et al., 2011). The Anthropocene as a concept was recovered by the Nobel Prize winner Paul Crutzen in 2002, succeeding the term 'antropozoico' coined by the Italian geologist Antonio Stoppani in 1871-73 and Anthropogenesis ideas of changes in the nature referred to by Paul Marsh in 1864 (Zalasiewicz et al., 2011: 835). The Anthropocene specifically refers to the changes brought up by humanity since the beginning of the industrial revolution (in the last two centuries) and was summarized by Zalasiewicz (Zalasiewicz et al., 2008: 5-6) in the following four points: changes in physical sedimentation; disturbance in the carbon cycle and temperature; biotic change and oceanic changes. The issues of the Anthropocene are discussed in a broad, interdisciplinary way and are mainly criticized by a Marxist mindset. Above all, they argue on the foundation of a Capitaloscene (Moore, 2017: 59), considering the crisis of the Anthropocene as more than just a geological change, therefore, discussing it on a sociopolitical level. From a humanistic and artistic point of view we can also refer to an Aquatocene which focuses on the phenomenon of underwater noise pollution created by humankind in the seas and oceans (Sebjanic, 2017). As Andrew Barry and Mark Maslin from the Anthropocene Working Group argue (Barry and Maslin, 2016), it is more than necessary to debate the urgency of a new regime of global environmental governance. Furthermore, Žižek (2004: 72) points out: „The Anthropocene is not so much a marker of an epochal transformation but a manifestation of an era in which democratic political debate has been displaced by a concern with the demands of economic management and the views of 'enlightened specialists' ". Anthropocene's consciousness is concomitant to the need for new global societal responses to that situation. The debate is far from over, by now the process seems to be analyzed through the perspective of social sciences. Tickell considers that exactly such societal responses imply to create institutional means to deal with global problems (population growth, consumer economy, energy issue, climate destabilization, loss of biodiversity) in a world where society is more interdependent than ever before (Tickell, 2011). All these issues refer to a need for governance in the context of sustainable development, what leads us to the 'resilience thinking' by Walker and Salt (Walker et al., 2006). The 'resilience thinking' involves several central concepts such as "thresholds, the adaptive cycle, panarchy, resilience, adaptability, and transformability" (Pisano, 2012: 6). What Pisano tells us is that the socio-ecological systems are resilient and if we are to govern such systems, we must adopt a resilience thinking within the framework of that governance: "The resilience perspective shifts from policies those that aspire to control change in systems assumed to be stable, to managing the capacity of social-ecological systems to cope with, adapt to, and shape change" (Pisano, 
2012: 6). Thus, resilience thinking requires adaptive governance following specific principles: "polycentric and multi-layered institutions, participation and collaboration, self-organization and networks, learning and innovation" (id., 2012: 7). The challenge seems to build a learning, cognitive society as a response to the context of the Anthropocene. We propose that this is the reason for the Programmatic Ambivalence in the post-2015 Agenda itself.

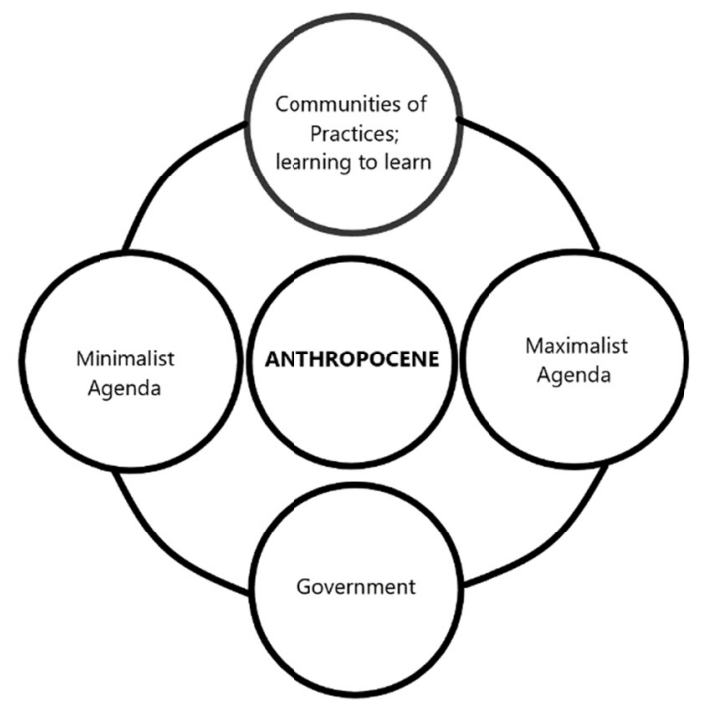

Figure 2. A Programmatic Ambivalence

Source: Elaboration of the authors

The main target of the concept for a Programmatic Ambivalence lies in the interaction of the Government with the Anthropocene and $\mathrm{CoP}$ to make a difference for changing the planet, therefore dealing with socio-ecological consequences from a bottom-up movement. The Anthropocene is a socio-structural product with natural consequences that requires answers in a sense of a political-syncretic social and political ambivalence, so, the Programmatic Ambivalence, what could make a difference in the social causality. To provide an effective change of the planet, every entity needs to take its place - from top-down to bottom-up. This leads us back to the necessity of the discussion about the Minimalist/Maximalist agenda to achieve a transformational process. Additionally, the debate about the influence of a Programmatic Ambivalence on further learning paths within the process of transformations needs to be outlined. Throughout demonstrating the way towards the Programmatic Ambivalence, it is mandatory to point out some of the foundations of the post-2015 Agenda. The preparation for the SDG was a much more participated process than the one of the MDG. All the documents for the groundwork of the post-2015 Agenda present an evidence of a Programmatic Ambivalence in which, besides a list of concrete goals and targets, a set of reflexive dimensions is also considered.

Our argument here is that this is the evidence of the agenda as a learning path itself and that the main goal of 'Transforming all lives' may only be achieved by a double bound process: a closed top-down agenda of concrete goals and targets assisted by open reflexive dimensions that may work as an open bottom-up agenda, as pedagogic guidelines for change and general contexts of balance, monitoring and evaluation. In this case it has to be referred that a global artificial intelligence is being organized and that this requires not only to do what must be done, but also to think about what is being done in order to do it better. If the goals and targets work as an agenda for action, then principles or dimensions work as a reflexive agenda and both are the evidence of a learning experience to promote learning paths.

Three documents among others may be presented as manifestation of the Programmatic Ambivalence.

I. The Report of the UN System Task Team on the Post-2015 UN Development Agenda prepared for the Secretary-General entitled "Realizing the Future We Want for All", June 2012. In the summary it is stated that the post-2015 agenda format should be based on concrete goals and targets, following one of the strengths of the MDGs, but should be reorganized into three key principles (Human Rights, Equality and Sustainability) as well as four dimensions of a more holistic 
perspective: 1) inclusive social development, 2) inclusive economic development, 3) environmental sustainability, 4) peace and security.

II. The High-Level Panel Report - A New Global Partnership: Eradicate Poverty and Transform Economies Through Sustainable Development (May 2013). It presents a 'Roadmap' for the passage of the MDG for the SDG. This view is shown as a function of 5 transformative turns and is complemented by a set of 12 goals and 54 targets. However, the Panel recommends that the number of objectives and targets agreed in the post-2015 agenda is limited and "SMART": specific, measurable, attainable, relevant and time-bound (specific, measurable, achievable, relevant and time) (2013: 13).

III. The General Secretary Report - "A life of Dignity for all" (delivered in July and presented in September). The report states that in order to entrench the sustainable development agenda, it is necessary to reach an agreement on four grounds: a) a vision firmly anchored in human rights and values and universally accepted principles, including the Declaration of the Human rights and the Millennium Declaration, b) a set of goals and targets for achieving the priorities of the agenda, c) a global partnership for development to mobilize the means of implementation, d) a participatory monitoring framework to track progress and mutual accountability of all partners. Afterwards, the report proposes 15 goals and a set of changes and actions to be considered by all countries in a mutually coordinated manner.

The outline of these three leading reports on the Programmatic Ambivalence direct us to the debate about the 2030 Agenda for sustainable development and its thoughts on the ambivalence between Minimalist/Maximalist.

\subsection{The Minimalist/Maximalist Ambivalence Reinforced}

Until September 2015, 'The Road to Dignity by 2030' was the main policy document of the post-2015 agenda that we had. This clearly reinforced the Programmatic Ambivalence stated on this paper, institutionalizing a scheme and requiring an interpretation for it. Remarkably, the final document on the SDG agenda (UN 2015) does not reproduce the six dimensions scheme. Instead, the resolution and final publication presents the minimal agenda in the preamble, considering that goals and targets may be comprehensive as action over "areas of critical importance for humanity and the planet". These areas are no longer six dimensions as in the 2014 document, but instead five so-called 'Ps' (People, Planet, Prosperity, Peace, Partnership). It seems obvious that a mnemonic process was put in place as to substitute 'Dignity' and 'Justice' by 'Peace'. 'People' includes the five first Goals; 'Planet' includes de $6^{\text {th }}$ and the $12^{\text {th }}$ to the $16^{\text {th }}$ Goals; 'Prosperity' includes the $7^{\text {th }}$ to the $11^{\text {th }}$ Goals and, finally, 'Peace' and 'Partnership' coincide respectively with the $16^{\text {th }}$ and the $17^{\text {th }}$ Goals. In the following section the importance of a transformational challenge for Community of Practices in order of a bottom-up / top-down development within the Anthropocene will be addressed.

\section{Results}

\subsection{Promoting Learning Experiences Everywhere: A Transformational Challenge within Communities of Practices}

Both the preparation of the 2015 agenda and the policy document seem to constitute a kind of cognitive planet. This means a conscience of the Anthropocene and a process (what may be called a learning path) to respond to the challenges of the Anthropocene. The learning path is conceived as two ways of thinking that must mutually interact (the ordinal list and the circular visualization). This is an obvious metaphor of the left and right brain, means and ends, actions and reflexive thinking and more. The left-brain processes information from the particular to the whole through a linear approach within an inductive pattern: take pieces of information, put them in a logical order, reflect on this structured information and reach a conclusion. The right side of the brain processes from the whole to the parts within a deductive complex, beginning with the answer by examining the first big picture, not the details (Nielsen et al., 2013). The dominance on the right side emphasizes the purpose for actions: the "big picture" prepares and absorbs the more detailed information that will come later. Instead, and complementarily, the dominance of the left side emphasizes the means and targets to achieve bigger goals, anchoring in real actions believing that the big picture will be clear later. For a better comprehension, the pursuing graphic pictures the learning path in relation to the concept of the ordinal list and the circular visualization. 
Table 2. The process of a learning experience

\begin{tabular}{cc}
\hline Ordinal list (Left brain) & Circular visualization (right brain) \\
\hline Top-Down (achieving, controlling) & Bottom-up (participation, collaboration) \\
from particular to general (Inductive thinking) & From general to detail (holistic thinking) \\
To do what must be done & to think about what is being done \\
\hline Agenda for Action (means) & Reflexive Agenda (ends) \\
\hline Actions as self-legitimated & Purpose as crucial for action \\
From targets to goals & From final answers to actions \\
Rational process & Adaptive process \\
\hline
\end{tabular}

Source: Elaboration of the authors

Therefore, transformational methodologies are a necessary demand because if all communities are obligated to turn into active learning entities for the opportunity of embodying this transformational approach, educational institutions must have a core role on that process. Hence, we present an intervention in form of a project of learning practices as proposal on this path. To continue with the debate about $C o P$, the following chapter prepares further perception to the empirical project of experimental exploratory transformations held through qualitative methods.

\subsection{Exploratory Transformational Experiments with Communities of Practices}

Throughout the second half of 2015, several exploratory experiments towards promoting Transformational CoP were set up in different contexts: a small city; a citizen science event; a college courtyard and a neighborhood square. These experiences were set up for testing and improving a research for change methodology as to advertise effective Transformational $\mathrm{CoP}$.

Through these experiences two different approaches were developed: the extended experiment, carried on in a Portuguese city (Viana do Castelo, Portugal) and the 'Fast Science' experiment, that was tested in the other realms (all in Lisbon, Portugal), which will be shown in the following graphics.
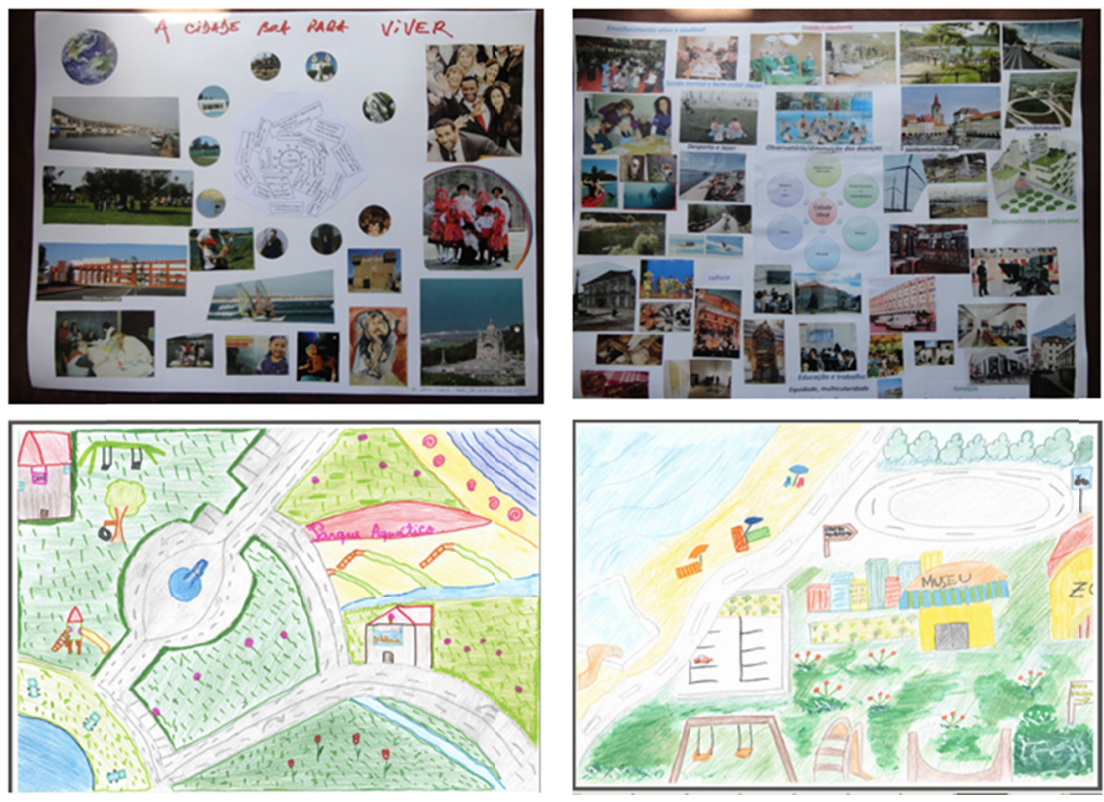

Image 1. The extended experiment: Senior and junior 'Good City to Live' mapping examples

Source: Seixas, P., R. Dias, P. Pedeira (2018)

In this version of the project, schools are considered core stages for a citizen audit regarding their own city. A participatory and collaborative research is carried on in two different school contexts (a U3A - a university of the third age and a primary/elementary school). The action-research based on a citizen science paradigm promotes 
artistic-reflexive works in a three-moments sequence. These moments constitute a continuum in the dialogue, collectivization and civic consciousness of a citizen audit regarding a specific city. Firstly, each class was divided in groups and with the task of using artistic techniques in a quite free way to create works on the topic "A Good City for Living". Secondly, all the groups present their results mutually and comment on their works first within their own class and afterwards through a cultural encounter of the two classes. Finally, all the works are presented to the public through an exhibit in a relevant civic center. In this third phase the fast science version is also put into place in a public space (usually a city park). Through this process, citizens are considered as researchers and civic activists in which seniors and juniors became peers to create a reflexive $C o P$ which projects urban public policies through images and subtitles that expand into oral universes of civic knowledge.

The following graphic shows the fast science experiment to enable a better understanding of its purpose.
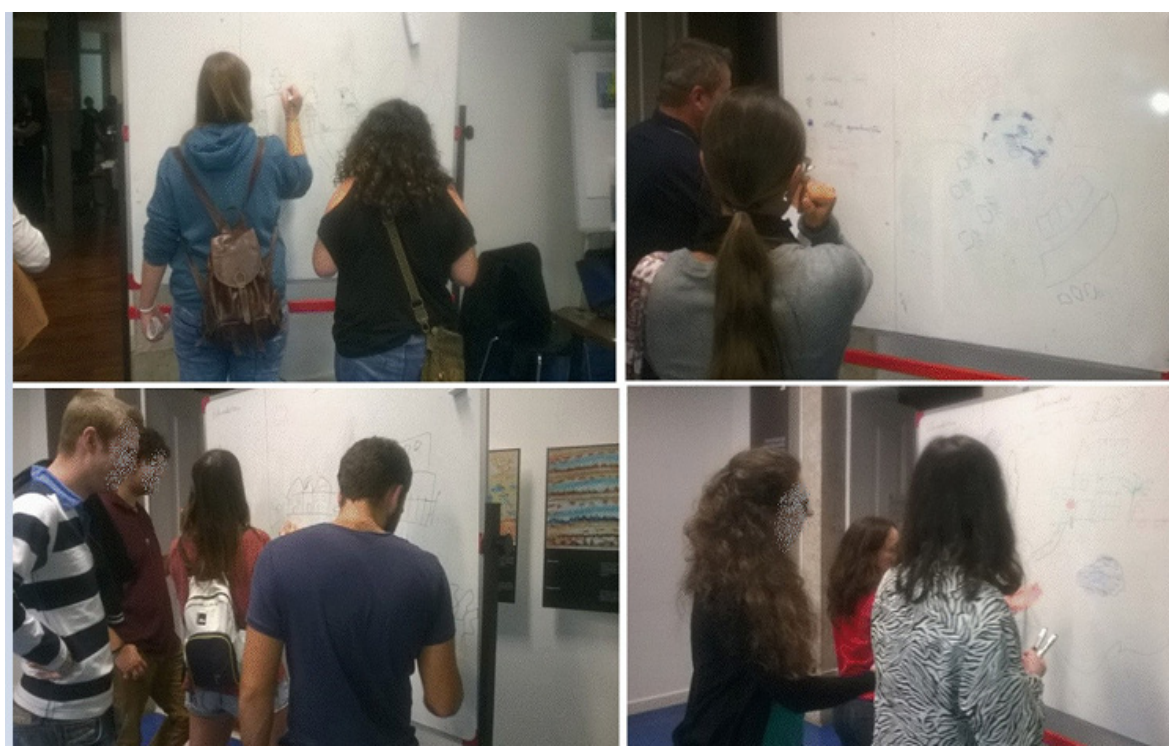

Image 2. The 'fast science' experiment in a Citizen Science Event (Lisbon, 2015)

Source: Seixas, P., R. Dias (2015)

In this version of the project (an indoor situation; a school courtyard and a neighborhood) we used a portable table in which we asked to draw individually or in groups a good city/good neighborhood to live in, plus the five changes that would transform it into better. After the participation of each group, a photo of the activity (drawing and list of changes) with the participants was printed just in time and given to the group within a frame untitled "Transformational Plan" as well as with the pattern of the SDG. The aim of the procedure was to create an ongoing reflexivity, possibly turning into a learning path and, eventually a Learning $C o P$.

\section{Final Remarks}

The greatest challenge of the twenty-first century is the governance of the resilience of the Anthropocene, understood as socio-eco-interdependence. SDG are, therefore, the first global public policy of the Anthropocene. This paper argues that this first global policy of the Anthropocene intends to present, more than anything, a way of thinking about the planet: basically, proposing a learning path for a cognitive planet. Furthermore, it seems patent that this learning path must be used (and for sure improved) to promote all social realms as learning paths: cities; organizations; neighborhoods; social groups; individuals. Considering this as a ground for action, this paper presented some reflective visions and methodologies to promote those learning paths.

Between 2012 and 2014 there was an intense debate on the post-2015 agenda and in December 2014 the first policy document with the proposed SDG came to light. The paper outlines that the debate and its outputs constitute an evidence of a problem and the exercise of different solutions in articulation.

It is proposed that the take off for this debate and the agenda itself were partly a collective conscience of the Anthropocene and of a global public policy to respond to it (Seixas, 2014). A Programmatic Ambivalence is considered to be in action (minimalist \& a maximalist approach) in the SDG agenda. According to that, the SDG document of 2014 - 'The Road to Dignity by 2030' (UN 2014) - as well as the final document issued in September 2015 - 'Transforming our world: the 2030 Agenda for Sustainable Development' - reinforce such an 
ambivalent approach. It is argued that this ambivalence is an expression of the required "learning path" of governance through a reflexive double bind (bottom-up and top-down) to promote a 'transformational approach'.

On this ground, it is suggested that the learning experiences shown by SDG are supposed to have hegemonic replication through a Lobby of People, challenging us all to the promotion of learning paths elsewhere and creating transformational Communities of Practice. If the Lobby of People must turn into Transformational CoP to embody this approach, educational institutions must for sure have a core role on that process as places to develop research for changing methodologies. Thus, some exploratory experiences are presented as processes to improve learning path situations for the actual creation of transformational $\mathrm{CoP}$.

We need cognitive cities, cognitive organizations, cognitive neighborhoods. In each of these realms, such a purpose requires a list of tasks and a big picture through which the purpose may be both rationalized and visualized. Both these techniques (and eventually others) are part of what transformational plans are. It is through discussions, elaborations and practices of transformational plans that such $C o P$ are created. The importance lies in the debate of a bottom-up and top-down development to enable a circulation of a connected participation between a macro- and microsphere, from people to people, from people to the government and from the government back to the people. Transformational communities and the Lobby of People are the best way to path a better future.

\section{References}

Barry, A., \& Maslin, M. (2016). The politics of the Anthropocene. Retrieved from http://onlinelibrary.wiley.com/doi/10.1002/geo2.22/full

Casagrande, M. (2015). Paracity: urban acupuncture. Rionero In Vulture: Oilforest League.

General Secretary Report. (2013). A life of Dignity for all. Retrieved from http://www.un.org/en/ga/search/view_doc.asp?symbol=A/68/202

Guivant, J. (2006). Ulrich Beck`s Legacy. Ambiente \& Sociedade - Volume XIX, 1, 227-237. Retrieved from http://www.academia.edu/28174721/ULRICH_BECKS_LEGACY

Helsinkiaccupuncture. (2013). Marco Casagrande: Urban Acupuncture. [Blogspot]. Retrieved from http://helsinkiacupuncture.blogspot.pt/

Lave, J., \& Wenger, E. (1991). Situated learning. Legitimate Peripheral Participation. Cambridge: Cambridge University Press. https://doi.org/10.1017/CBO9780511815355

Mohammed, A. (2013). Leaving No One Behind: Towards a Post-2015 Development Agenda. Retrieved from http://post2015.iisd.org/guest-articles/leaving-no-one-behind-towards-a-post-2015-development-agenda/

Moore, W. J. (2017). The Capitalocene, Part I: on the nature and origins of our ecological crisis. The Journal of Peasant Studies, 44(3), 594-630. https://doi.org/10.1080/03066150.2016.1235036

Nielsen, J., Zielinski, B., Ferguson, M., Lainhart, J., \& J. Anderson. (2013). An Evaluation of the Left-Brain vs. Right-Brain Hypothesis With Resting State Functional Connectivity Magnetic Resonance Imaging. Journal Plos One. Retrieved from: https://www.ncbi.nlm.nih.gov/pubmed/23967180

Pisano, U. (2012). Resilience and Sustainable Development: Theory of resilience, systems thinking and adaptive governance.

Retrieved

from http://unsdsn.org/files/2013/11/An-Action-Agenda-for-Sustainable-Development.pdf

Seixas, P. (2014). Objectivos de Desenvolvimento Sustentável: A Primeira Política Pública Global do Antropoceno. Revista Cientifica Monfrague -Desarrollo Resiliente -Volume II, $\mathrm{N}^{\circ}$ 2. Retrieved from http://www.monfragueresiliente.com/

Seixas, P., Dias, R., \& Pereira, P. (2017). A good city for living. Cultural planning and citizen science with sustainable urban development. A Obra Nasce, 12, 9-25. Retrieved from http://arquitectura.ufp.pt/docs/2018/04/AON12_FINAL.pdf

Shapeplatfrom. (2017). From Anthropocene to Aquatocene: An interview with Sebjanc R. Retrieved from http://shapeplatform.eu/2017/from-anthropocene-to-aquatocene-an-interview-with-robertina-sebjanic/

Tickell, C. (2011). Societal Responses to the Anthropocene. Philosophical Transactions of the Royal Society. Retrieved from http://rsta.royalsocietypublishing.org/content/369/1938/926.full.pdf + html

UN System Task Team. (2012). Realizing the Future We Want for All. Retrieved from http://www.un.org/millenniumgoals/pdf/Post_2015_UNTTreport.pdf 
UN System task team. (2013). Statistics and Indicators for the Post-2015 Development Agenda. Retrieved from http://www.un.org/en/development/desa/policy/untaskteam_undf/UNTT_MonitoringReport_WEB.pdf

UNHabitat. (2012). Sustainable cities and human settlements in the post-2015 UN development agenda. Retrieved from http://sustainabledevelopment.un.org/content/documents/1653SustainableCities.pdf

United Nations Department of Economic and Social Affairs. (2012). Final document Rio+20: The Future We Want. Retrieved from http://sustainabledevelopment.un.org/futurewewant.html

United Nations Development Group. (2013). The World We Want: A Milion Voices. Retrieved from http://www.worldwewant2015.org/millionvoices

United Nations General Assembly. (2014). The Road to Dignity by 2030: Ending Poverty, Transforming All Lives and Protecting the Planet. Retrieved from http://www.un.org/ga/search/view_doc.asp?symbol=A/69/700\&Lang=E

United Nations General Assembly. (2015). Transforming our world: the 2030 Agenda for Sustainable Development. Retrieved from http://www.un.org/ga/search/view_doc.asp?symbol=A/RES/70/1\&Lang

United Nations High Level Panel on Global Sustainability Report. (2013). Resilient People Resilient Planet. A Future Worth Choosing. Retrieved from http://www.un.org/gsp/sites/default/files/attachments/GSP_Report_web_final.pdf

United Nations High Level Panel Report. (2013). A New Global Partnership: Eradicate Poverty And Transform Economies Through Sustainable Development. Retrieved from http://www.post2015hlp.org/wp-content/uploads/2013/05/UN-Report.pdf

Visser, W. (2015). Transforming our world. Retrieved from http://www.waynevisser.com/report/sdgs-finalised-text

Walker, B., \& Salt, D. (2006). Resilience thinking: sustaining ecosystems and people in a changing world. Washington: Island Press.

Wallace, A. (1956). Revitalization Movements. American Anthropologist, 58(2), 264-281. https://doi.org/10.1525/aa.1956.58.2.02a00040

Waters, N. et al. (2016). The Anthropocene is functionally and stratigraphically distinct from the Holocene. Science Journal, 1-26. https://doi.org/10.1126/science.aad2622

Wenger, E. (1998). Communities of Practice. Learning, Meaning and Identity. Retrieved from http://www.un.org/en/development/desa/policy/wess/wess_current/wess2013/WESS2013.pdf

Wenger, E., McDermott, R., \& Snyder, W. (2002). Cultivating Communities of Practice: A Guide to Managing Knowledge. Boston, Massachusetts: Harvard Business School Press,

Zalasiewicz, J. et al. (2008). Are we now living in the Anthropocene? Retrieved from http://www.geosociety.org/gsatoday/archive/18/2/pdf/i1052-5173-18-2-4.pdf

Zalasiewicz, J., Williams, M., \& Haywood, A. (2011) The Anthropocene: a new epoch of geological time? Philosophical Transactions of the Royal Society, 369, 835-41. https://doi.org/10.1098/rsta.2010.0339

Žižek, S. (2004). Afterword to The politics of aesthetics by Jacques Rancier. London: Continuum.

\section{Copyrights}

Copyright for this article is retained by the author(s), with first publication rights granted to the journal.

This is an open-access article distributed under the terms and conditions of the Creative Commons Attribution license (http://creativecommons.org/licenses/by/4.0/). 